\title{
CELLULASE AND XYLANASE IMMOBILIZED ON CHITOSAN MAGNETIC PARTICLES FOR APPLICATION IN COCONUT HUSK HYDROLYSIS
}

\author{
Afan Hamzah ${ }^{1}$, Sidratu Ainiyah ${ }^{1}$, Dwi Ramadhani ${ }^{1}$, Gek Ela Kumala Parwita ${ }^{1}$, Yeni \\ Rahmawati $^{1}$, Soeprijanto ${ }^{1}$, Hiroyasu Ogino ${ }^{2}$, Arief Widjaja ${ }^{1 *}$ \\ ${ }^{1}$ Department of Chemical Engineering, Institut Teknologi Sepuluh Nopember, Surabaya 60111, \\ Indonesia \\ ${ }^{2}$ Department of Chemical Engineering, Osaka Prefecture University, 1-1 Gakuen-cho, Naka-ku, \\ Sakai, Osaka 599-8531, Japan
}

(Received: July 2018 / Revised: October 2018 / Accepted: April 2019)

\begin{abstract}
Cellulase and xylanase were covalently immobilized on chitosan magnetic particles. They were employed as catalysts to produce reducing sugar from coconut husk individually and simultaneously. Fourier Transform Infrared Spectroscopy (FT-IR) and Bradford's protein analysis confirmed that the enzymes were covalently immobilized on the support. Cellulase from Aspergillus niger and Trichoderma reesei immobilized on chitosan magnetic microparticles yielded $0.352 \mathrm{~g} / \mathrm{L}$ and $0.316 \mathrm{~g} / \mathrm{L}$ of reducing sugar respectively, while immobilized xylanase from Trichoderma longibachterium yielded $0.432 \mathrm{~g} / \mathrm{L}$. The simultaneous use of cellulase and xylanase produced $0.8034 \mathrm{~g} / \mathrm{L}$ of sugar, and the addition of glutaraldehyde as a cross-linking agent increased the amount of reducing sugar. Enzyme could maintain its activity at $91 \%$ for up to five cycles. Using nanosized particles resulted in a sugar yield of 0.49 $\mathrm{g} / \mathrm{l}$ and $54.7 \%$ of its activity maintained after five cycles.
\end{abstract}

Keywords: Cellulase; Chitosan magnetic particles; Coconut husk; Immobilization; Xylanase

\section{INTRODUCTION}

Lignocellulose can be converted to reducing sugar for biofuels since it consists of cellulose, hemicellulose and lignin (Alftrén \& Hobley, 2014). Coconut husk, which is an abundant lignocellulosic substrate in Indonesia, is a valuable substance as a future source of energy. However, the complex structure of lignocellulosic substrate is a major obstacle in its degradation process. The most widely known method to degrade lignocellulose is by chemical or physical pre-treatment, followed by hydrolysis. Enzymatic hydrolysis has been proven to improve the yields of sugar produced, has high selectivity, low energy costs and mild operating conditions (Zang et al., 2014). However, the expense of the enzyme and its specific activity for particular substrates are drawbacks in the application on a complex substrate such as lignocellulose (Han et al., 2018; Song et al., 2016).

The combination of xylanase and cellulase has numerous advantages; for example, xylanase can degrade the xylan which is attached to the cellulose surface and block the access of cellulase to cellulose (Mardawati et al., 2018). Since xylose is generated from xylan hydrolysis, the addition

${ }^{*}$ Corresponding author's email: arief_w@chem-eng.its.ac.id, Tel. +62-31-5946240, Fax. +62-31-5999282

Permalink/DOI: https://doi.org/10.14716/ijtech.v10i3.2905 
of xylanase not only makes the cellulose accessible to cellulase but at the same time also generates more sugar (Jia et al., 2015). The use of multiple enzymes simultaneously can also be

achieved by utilizing crude enzyme. Crude enzyme from A. niger contains numerous enzymes, including cellulases and xylanases. Furthermore, utilizing crude enzyme will make the overall process more economical. The other strategy for employing the enzymes more economically is by reusing them in the hydrolysis reaction through immobilization. This also improves their stability and adaptability in various conditions, such as temperature and $\mathrm{pH}$ (Han et al., 2018).

Covalent binding is commonly used as an immobilization technique, since it restricts leaching of the enzyme because of the stable covalent bond with the support (Cheng-Kang \& Au-Duong, 2018). Cellulase has been shown to be able to covalently immobilize on the surface of carrageenan (Yuan et al., 2016); polystyrene, polypropylene and polyethylene (Ahirwar et al., 2017); and chitosan (El-Ghaffar \& Hashem, 2010; Manrich et al., 2010). In addition, xylanase has been shown to covalently immobilize on chitosan (Manrich et al., 2010); alginate beads (Jampala et al., 2017); and magnetic nanoparticles (Soozanipour et al., 2015; Shahrestani et al., 2016). As support for enzyme immobilization, chitosan, a natural polymeric support, has previously been reported to have the ability to support cellulase and xylanase since it has various functional group, and is inexpensive, inert, hydrophilic and biocompatible (Osuna et al., 2012). Micro-sized and nanosized chitosan magnetic particles were used since their larger surface area will resolve the mass transfer resistance between the immobilized enzyme and the substrate. Chitosan will act as a coating on the magnetic particles as it delivers a functional group for covalent binding. To enhance the binding, a cross-linking agent, glutaral dialdehyde (GDA), was also supplemented (Sojitra et al., 2017). Magnetic separation from the complex samples can be performed easily using an external magnetic field (Chen et al., 2014).

The objective of this work is to study the utilization of cellulase and xylanase immobilized on chitosan magnetic particles in coconut husk hydrolysis and the simultaneous effect of using a mixture of enzymes.

\section{METHODS}

\subsection{Materials}

Coconut husk, which was obtained from North Sulawesi, Indonesia, was dried and screened until it reached 100-120 mesh. It was then pre-treated using $\mathrm{NaOH} 1 \%(w / v)$ at $80^{\circ} \mathrm{C}$ for $16 \mathrm{~h}$. Xylanase from $T$ longibrachiatum cellulase from $T$ reesei, cellulase from $A$ niger, magnetic particles $\left(\mathrm{Fe}_{3} \mathrm{O}_{4}\right) \pm 5 \mu \mathrm{m}$ diameter size, bovine serum albumin (BSA), chitosan low molecular weight, Iron (II) chloride tetrahydrate, Iron (III) chloride hexahydrate, ammonium hydroxide $\left(\mathrm{NH}_{4} \mathrm{OH}, 28 \mathrm{wt} \%\right)$, acetic acid and 3,5-dinitrosalicylic acid were purchased from SigmaAldrich. Glutaral dialdehyde and other chemicals were purchased from Merck.

\subsection{Preparation of Chitosan Magnetic Microparticles}

Chitosan magnetic microparticles were prepared using the method employed by Biró et al. (2008) and Safarik et al. (2012) with some modification. Four grams of chitosan and 8 grams of magnetite particles were dissolved in $200 \mathrm{~mL}$ of $0.2 \mathrm{M}$ acetic acid. After thorough mixing, an excess of $1 \mathrm{M}$ sodium hydroxide was added to convert the solubilized chitosan into insoluble form. The chitosan containing entrapped magnetite microparticles was freeze-dried and washed with water several times.

\subsection{Preparation of Chitosan Magnetic Nanoparticles}

Chitosan magnetic nanoparticles were prepared using the method developed by Zang et al. (2014). Iron (II) chloride tetrahydrate and Iron (III) chloride hexahydrate was reacted together in $50 \mathrm{~mL}$ of deionized water, followed by the addition of $\mathrm{NH}_{4} \mathrm{OH}$ to form magnetic nanoparticles. The reaction was carried out at $80^{\circ} \mathrm{C}$ for $2 \mathrm{~h}$ with $\mathrm{N}_{2}$ protection. The magnetic 
nanoparticles were supplemented by chitosan solution and $\mathrm{NaOH}$ was added to complete their preparation.

\subsection{Immobilization}

The immobilization process used the method of El-Ghaffar \& Hashem (2010), with some modification. Magnetic chitosan $0.1 \mathrm{~g}$ was added to the enzyme solution ( $6 \mathrm{mg}$ protein). The immobilization reaction was carried out for $24 \mathrm{~h}$ at $25^{\circ} \mathrm{C}$ in a shaking incubator. The precipitates and the unbound enzyme were eliminated by washing them with a phosphate buffer and by magnetic separation. The liquid was then analyzed to determine the concentration of the unbound protein. The immobilized enzymes were stored at $4{ }^{\circ} \mathrm{C}$ until their use. For immobilization on chitosan with a glutaric dialdehyde supporter, chitosan magnetic was added to a glutaric dialdehyde solution $2.5 \%(\mathrm{v} / \mathrm{v})$ and kept in a shaking incubator for $4 \mathrm{~h}$ at $25^{\circ} \mathrm{C}$ before the enzyme was added.

\subsection{Enzymatic Hydrolysis}

$0.1 \mathrm{~g}$ immobilized enzyme was added to $1 \mathrm{~g}$ pre-treated coconut husk in a $20 \mathrm{~mL} \mathrm{pH} 7$ phosphate buffer, and the hydrolysis process was carried out for $48 \mathrm{~h}$ at $125 \mathrm{rpm}$ and $60^{\circ} \mathrm{C}$. The mixture was centrifuged $\left(10,000 \mathrm{rpm}, 4^{\circ} \mathrm{C}\right)$ and the resulting liquid was analyzed for its reducing sugar content.

\subsection{Reusability Study}

$0.1 \mathrm{~g}$ immobilized enzyme was utilized to hydrolyze $1 \mathrm{~g}$ pre-treated coconut husk in $20 \mathrm{~mL} \mathrm{pH}$ 7 phosphate buffer at $60^{\circ} \mathrm{C}$ for $48 \mathrm{~h}$. After separation by a magnet, the immobilized cellulase was washed with the buffer, and then suspended again in a fresh reaction mixture. The reusability study was repeated for five cycles. The glucose productivity during the $48 \mathrm{~h}$ was used to evaluate the reusability of the enzyme.

\subsection{Analytical Method}

The morphology and size of the chitosan microparticles and nanoparticles were examined using SEM (Scanning Electron Microscopy) (inspect s50, Netherlands) and TEM (Transmission Electron Microscopy) (JEOL JEM 1400), respectively. The FT-IR spectra were measured using an FT-IR spectrometer (Thermo Scientific, US), while the protein content was analyzed by the Bradford method using bovine serum albumin as standard (Bradford, 1976). The reducing sugar was analyzed by the DNS (Dinitro salicylic acid) method to ascertain its concentration (Miller, 1959).

\subsection{Statistical Analysis}

Analysis of Variance (ANOVA) was employed to verify the significance of temperature, mixing speed and enzyme concentration in immobilization yield and to study the significance of enzyme combination in reducing sugar yield, using Minitab 16 (Minitab Inc., ITS Surabaya, Indonesia).

\section{RESULTS AND DISCUSSION}

\subsection{Morphology and Size of Support}

Three kinds of support were prepared for the immobilization, namely chitosan macroparticles, chitosan magnetic microparticles and chitosan magnetic nanoparticles. The chitosan macroparticle had a $>1000 \mu \mathrm{m}$ diameter size, and no special preparation was involved in creating them. The chitosan magnetic microparticles were prepared by utilizing the chitosan characteristic of being soluble in acidic solution. The commercial magnetic particles were added to this solution. After vigorous stirring, $\mathrm{NaOH}$ was added to transform the chitosan into insoluble magnetic particles entrapped within it, as shown schematically in Figure 1 (Pospiskova \& Safarik, 2013). From the SEM micrograph in Figure 2a, the chitosan magnetic microparticles had an irregular shape and were $<500 \mu \mathrm{m}$ in diameter size. The synthesis of the 
chitosan nanoparticles followed almost the same method and principle as that of the microparticles. The only difference was that the magnetic $\mathrm{Fe}_{3} \mathrm{O}_{4}$ particles were made using $\mathrm{FeCl}_{3}$ and $\mathrm{FeCl}_{2}$, and amount of chitosan added was less than that of the microparticles (Zang et al., 2014). Figure $2 b$ shows a TEM micrograph of the nanoparticles. The chitosan magnetic nanoparticles had a uniform spherical shape and were $<50 \mathrm{~nm}$ in size.

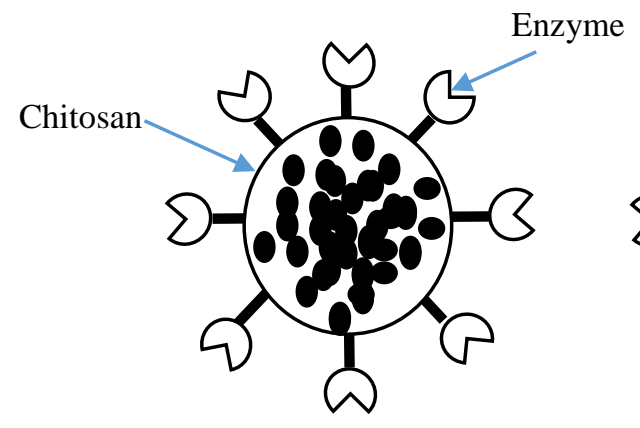

(a)

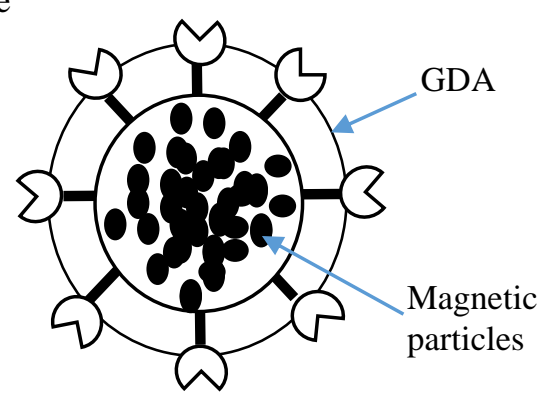

(b)

Figure 1 Illustration of: (a) enzyme covalently immobilized on chitosan magnetic particles; and (b) enzyme covalently bonded and crosslinked to chitosan magnetic particles + glutaral dialdehyde (GDA)

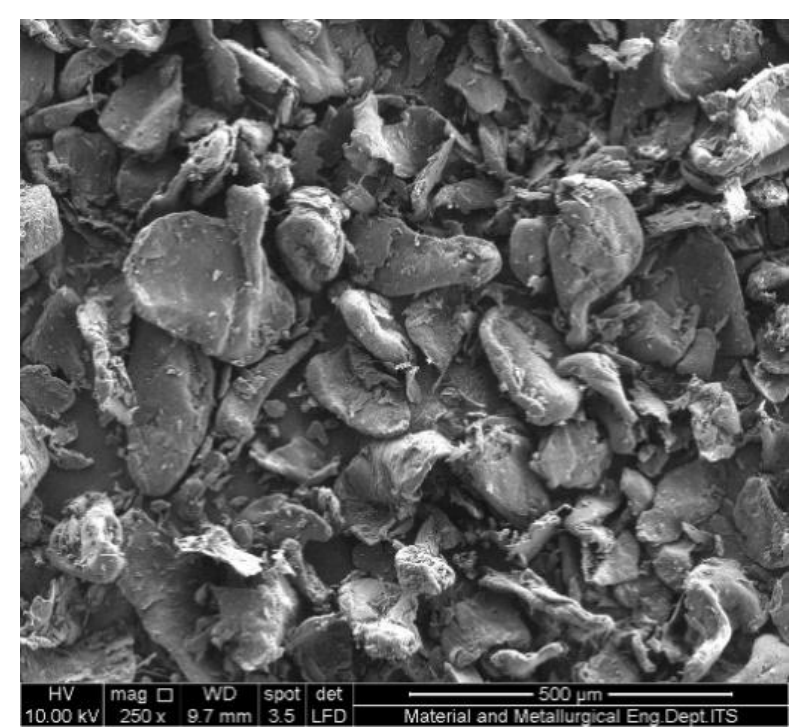

(a)

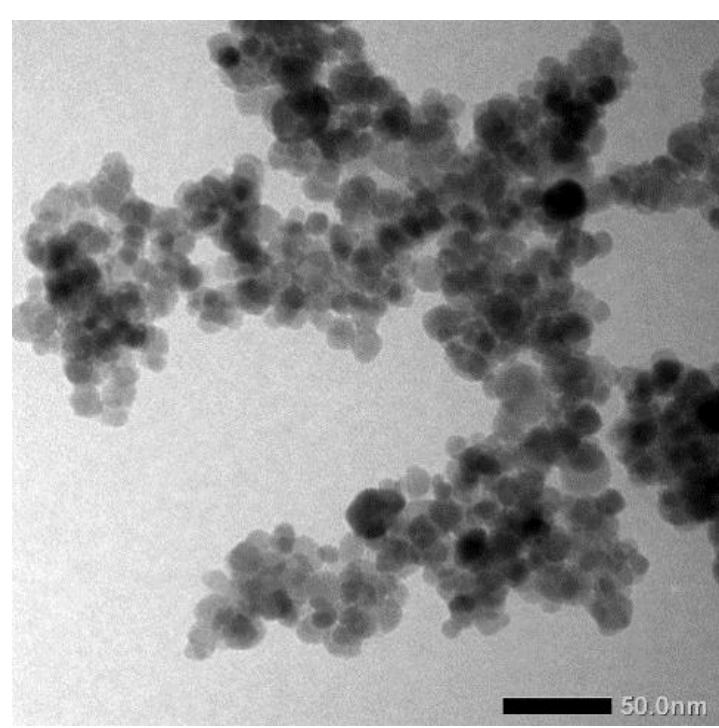

(b)

Figure 2 (a) SEM micrograph of chitosan magnetic microparticles with $500 \mu \mathrm{m}$ scale bar; and (b)TEM micrograph of chitosan magnetic nanoparticles with $50 \mathrm{~nm}$ scale bar

\subsection{Immobilization}

Immobilization yield was affected by temperature, mixing speed and enzyme concentration; the effect of these factors was also studied. Neither temperature nor mixing speed had a significant effect $(p>0.05)$ on the yield, but the concentration of added enzyme solution had a significant effect ( $\mathrm{p}<0.05)$ (data not shown). It was determined that $6 \mathrm{mg}$ of protein was the optimum concentration of enzyme to add to the support. Cellulase from A niger and $T$ reese $i$ was able to retain a $100 \%$ immobilization yield, while xylanase from $T$ longibrachiatum retained $88 \%$, as determined by the Bradford analysis and shown in Table 1. The immobilization yield of xylanase was lower than that of cellulose, which may be due to the lack of amino groups in chitosan, and which led to incomplete immobilization (Sánchez-Ramírez et al., 2017; Xu et al., 
2011). The amino groups could be calculated by the Ninhydrin assay and NMR (Mahon et al., 2015).

Table 1 Immobilization enzyme yield

\begin{tabular}{lccc}
\hline \multicolumn{1}{c}{ Enzyme } & $\begin{array}{c}\text { Initial protein } \\
(\mathrm{mg})\end{array}$ & $\begin{array}{c}\text { Immobilized } \\
(\mathrm{mg})\end{array}$ & $\begin{array}{c}\text { \% immobilization } \\
\text { yield }\end{array}$ \\
\hline Cellulase from T reesei & 6 & 6 & $100 \%$ \\
Cellulase from A niger & 6 & 6 & $100 \%$ \\
Xylanase from T longibrachiatum & 6 & 5.28 & $88 \%$ \\
Cellulase from T reesei with GDA & 6 & 6 & $100 \%$ \\
Cellulase from A niger with GDA & 6 & 6 & $100 \%$ \\
Xylanase from T Tongibrachiatum with GDA & 6 & 6 & $100 \%$ \\
\hline
\end{tabular}

However, the procedure was not performed because all the enzymes reached $100 \%$ coupling with the addition of GDA, which was shown to provide more functional groups available for enzyme binding (Yuan et al., 2016). The other possible reason was the incompatibility of the $\mathrm{pH}$ solution and the solubility of xylanase and chitosan, which meant the isoelectric point of the immobilization process was not optimal (Jia et al., 2015).

From previous research conducted by El-Ghaffar \& Hashem (2010), the possible binding between enzymes and support is illustrated in Figure 1a. Figure 1b shows a combination between a covalent bond and the cross-linking method using GDA. It can be seen from the figure that amino groups of chitosan were bonded directly with the carboxylic terminal residue in the enzymes. This reaction was also confirmed by Fourier Transform Infrared (FT-IR) spectra, as shown in Figure 3. As seen in the figures, there were significant changes in the peak in wavelength $3272.53 \mathrm{~cm}^{-1}$, that was the characteristic of the amino group $(\mathrm{N}-\mathrm{H})$; wavelength $1632.67 \mathrm{~cm}^{-1}$, which was the characteristic of $\mathrm{C}=\mathrm{O}$; and wavelength $1080 \mathrm{~cm}^{-1}$, that was the characteristic of aliphatic amide C-N (Mistry, 2009). This indicates that enzyme has been immobilized on the chitosan. The FT-IR spectra of enzyme immobilized on chitosan-GDA can be seen in Figure 3. This figure shows that there are also some significant changes in the peak in wavelength $3267.54 \mathrm{~cm}^{-1}(\mathrm{~N}-\mathrm{H}) ; 1629.15 \mathrm{~cm}^{-1}(\mathrm{C}=\mathrm{O}) ; 1027.66 \mathrm{~cm}^{-1}(\mathrm{C}-\mathrm{N})$, which is same as cellulase-chitosan; and wavelength $1376.0 \mathrm{~cm}^{-1}(\mathrm{C}-\mathrm{O})$, indicating that GDA functioned as a cross-linking agent and spacer arm in the covalent binding.

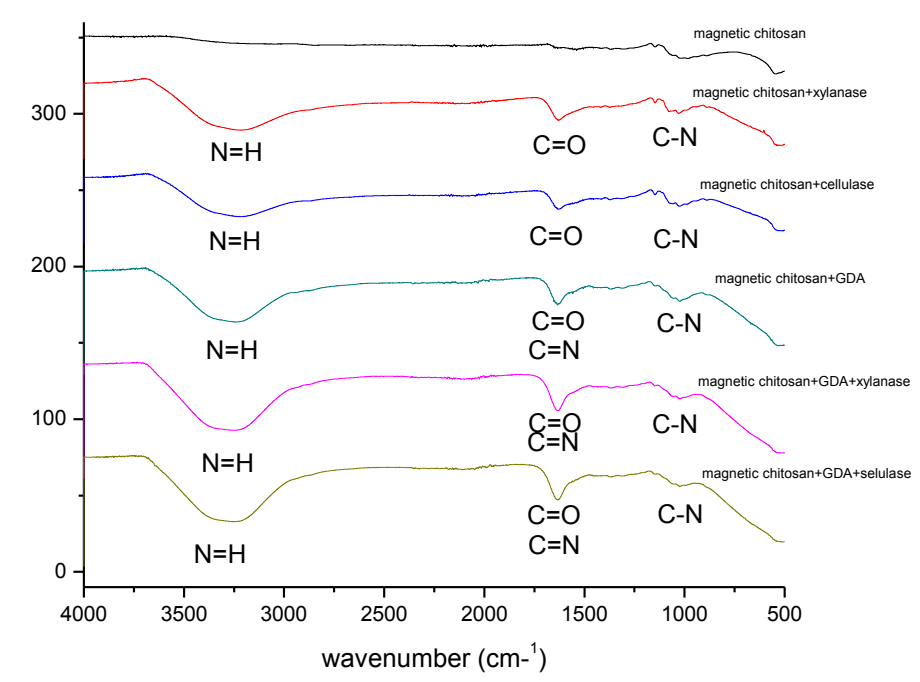

Figure 3 FT-IR spectra of support and immobilized enzymes 


\subsection{Effect of Support Particle Size}

Table 2 summarizes the performance comparison between different-sized chitosan. Although the chitosan microparticles and nanoparticles had fewer coupled enzymes than the macroparticles, they yielded almost the same amount of sugar.

Table 2 Yield of reducing sugar from different sizes of chitosan

\begin{tabular}{lccc}
\hline \multicolumn{1}{c}{ Immobilized enzyme } & Enzyme coupling $(\mathrm{mg})$ & Specific activity & Yield $^{*}$ \\
\hline Chitosan macro+ crude enzyme & 11.84 & 0.21 & 0.035 \\
Chitosan macro+ cellulase & 38.35 & 1.94 & 0.040 \\
Chitosan micro+ cellulase & 5.50 & 1.94 & 0.040 \\
Chitosan nano+ cellulase & 4 & 1.94 & 0.037 \\
\hline
\end{tabular}

*Yield: gr reducing sugar/gr (cellulose+hemicellulose)

Furthermore, the nanoparticles had less coupled enzymes than the microparticles, but yielded nearly the same amount of sugar. The data revealed that mass transfer resistance was reduced by utilizing smaller support particles. These had a larger surface area and numerous active sites available for the enzyme molecules to be fixed (Biró et al., 2008).

\subsection{Utilization of Crude Enzyme}

Prior to determining the use of the combination of commercial cellulase and xylanase, crude enzyme from A. niger was applied in the hydrolysis of the coconut husk in its free and immobilized form. Crude enzyme has unique characteristics as it contains several enzymes, including cellulase and xylanase, as evidenced from the enzyme assay for both the enzymes (data not shown). Table 3 shows the yield of reducing sugar produced from coconut husk using various types of enzyme. The yield produced by either free crude enzyme or free commercial cellulase was higher than that of the immobilized form. This is because the solid coconut husk and chitosan support restricted the mass transfer of enzyme to the substrate. However, the decreasing yield of free crude and free commercial enzyme after immobilization was almost the same, at around $80 \%$. This shows that the crude enzyme produced in our laboratory also has good potential to be used in immobilized enzyme. Table 3 also shows the yield using enzyme immobilized on chitosan GDA, at around 0.057 for immobilized crude enzyme and 0.089 for the immobilized commercial type. These data also confirm the previous discussion, that either crude or commercial enzyme immobilized on chitosan GDA produced a larger yield than immobilization using chitosan only. Although the yield of sugar using immobilized enzyme is still under the free enzymes immobilization will be advantageous if it is used many times in a continuous process, so that productivity will be increased. The utilization of crude enzyme immobilized on chitosan had many deficiencies. Besides its low sugar yield production, the type of enzyme which was immobilized on the support could not be controlled; the covalent binding process was not able to be confirmed due to the numerous enzymes contained within it; and the inhibitor contained in the crude enzyme also hindered the immobilization process.

Table 3 Yield of reducing sugar from free enzyme and immobilized enzyme on the macroparticles

\begin{tabular}{|c|c|}
\hline Enzyme Type & Yield $^{*}$ \\
\hline Free crude enzyme & 0.176 \\
\hline Crude enzyme immobilized on chitosan & 0.035 \\
\hline Crude enzyme immobilized on chitosan-GDA & 0.057 \\
\hline Commercial cellulase & 0.320 \\
\hline Commercial cellulase immobilized on chitosan & 0.040 \\
\hline Commercial cellulase immobilized on chitosan-GDA & 0.089 \\
\hline
\end{tabular}




\subsection{Hydrolysis of Immobilized Enzyme on Microparticles and Nanoparticles}

The immobilized enzymes were applied to the coconut husk hydrolysis individually and simultaneously at different ratio. $6 \mathrm{mg}$ of protein was determined as the amount of enzyme to be applied to the hydrolysis individually and simultaneously. The w/w ratio of the two types of cellulase was determined to be 1:2, as this showed the best performance (data not shown). It has been previously shown that combining two types of cellulase from different sources enhances sugar yield, since the cellulases complement each other in terms of hydrolase (Hamzah et al., 2018). Cellulase from $T$ reesei yielded more exoglucanase and endoglucanase and lacked $\beta$-glucosidase. This shortage was complemented by cellulase from $A$ niger (Stockton et al., 1991). Table 4 shows the code and ratio of enzymes applied.

Table 4 Ratio of immobilized enzyme on chitosan magnetic microparticles based on the amount of protein

\begin{tabular}{ccccc}
\hline Code & $\begin{array}{c}\text { Immobilized } \\
\text { Cellulase from } \\
\text { Treesei }(\mathrm{mg})\end{array}$ & $\begin{array}{c}\text { Immobilized } \\
\text { Cellulase } \\
\text { from A niger } \\
(\mathrm{mg})\end{array}$ & $\begin{array}{c}\text { Immobilized } \\
\text { Xylanase from } T \\
\text { longibrachiatum } \\
(\mathrm{mg})\end{array}$ & $\begin{array}{c}\text { Ratio } \\
\text { Cellulase: } \\
\text { Xylanase } \\
(\mathrm{w} / \mathrm{w})\end{array}$ \\
\hline $\mathrm{A}$ & 6 & 0 & 0 & - \\
$\mathrm{B}$ & 0 & 6 & 0 & - \\
$\mathrm{C}$ & 0 & 0 & 6 & - \\
$\mathrm{D}$ & 2.676 & 1.338 & 1.986 & $2: 1$ \\
$\mathrm{E}$ & 2 & 1 & 3 & $1: 1$ \\
$\mathrm{~F}$ & 1.332 & 0.668 & 4 & $1: 2$ \\
\hline
\end{tabular}

Coconut husk containing $26.72 \%$ cellulose and $17.73 \%$ hemicellulose (Sangian et al., 2015) was converted to reducing sugar through enzymatic hydrolysis using several types of immobilized enzyme, as shown in Table 4 . The hydrolysis was performed at $60^{\circ} \mathrm{C}$ for $48 \mathrm{~h}$. Figure 4 shows the time taken to produce reducing sugar from the hydrolysis process. After 48 $\mathrm{h}$ of hydrolysis reaction, cellulase from $A$ niger and $T$ reesei yielded $0.352 \mathrm{~g} / \mathrm{L}$ and $0.316 \mathrm{~g} / \mathrm{L}$ of sugar, respectively, while immobilized xylanase from $T$ longibachterium yielded $0.432 \mathrm{~g} / \mathrm{L}$. Simultaneous use of different enzymes with codes D, E and F significantly improved the yield of reducing sugar to $0.751,0.8045$, and $0.8034 \mathrm{~g} / \mathrm{L}$, respectively. The simultaneous reaction by three kinds of enzyme had a significant effect on reducing sugar yield $(\mathrm{p}<0.05)$. Xylanase not only enhanced the quantity of sugar produced by its hemicellulose degradation to xylose, but also opened the access of cellulase to cellulose, which is blocked by hemicellulose, meaning sugar production was greatly improved (Song et al., 2016). As previously reported, in the application of the free form of cellulase and xylanase the combination of the two enzymes enhances sugar production (Farinas et al., 2010; Gonçalves et al., 2015; Pengilly et al., 2015). This study confirms that this was also true for immobilized enzyme. Code F, which had the best performance, was applied again to investigate the effect of GDA as the cross-linking agent, and it was shown to enhance the quantity of reducing sugar to $1.039 \mathrm{~g} / \mathrm{L} 0$. GDA, which was able to escalate the available amino groups, leading to an increase in and stabilization of the enzyme coupling, not only improved the sugar yield at the end of the process, but also every hour of the reaction. Without adding GDA, the active enzyme sites tend to overlap each other, and furthermore the solid form of both lignocellulose and immobilized enzymes may give higher resistance of the mass transfer between enzymes and substrates. GDA could decrease steric hindrance between enzyme and support, since it acts as a spacer between the enzyme and chitosan (El-Ghaffar \& Hashem, 2010). The F combination was also applied to nano-sized particles, but with only $4 \mathrm{mg}$ of protein, generating a sugar yield of $0.49 \mathrm{~g} / \mathrm{L}$. 


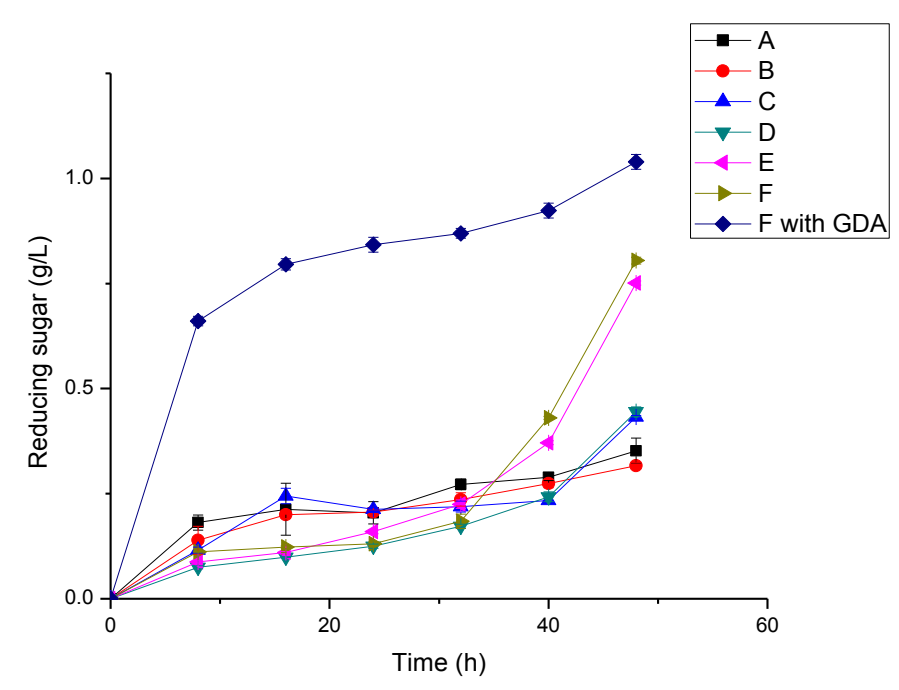

Figure 4 Timing of the hydrolysis of coconut husk by immobilized enzymes on chitosan magnetic microparticles as a biocatalyst. Codes A-F are the codes of the ratios of the enzyme combinations shown in Table 4

\subsection{Reusability of Immobilized Enzyme}

The reusability of immobilized enzyme was investigated with the F combination, with and without GDA. Figure 5 shows that cellulase immobilized directly on chitosan magnetic microparticles and on those cross-linked with GDA, retaining $91 \%$ and $75 \%$ of their initial activity respectively. The addition of the cross-linking agent enhanced the amount of reducing sugar produced. However, although it had less consistency in retained activity, it still produced more sugar than without GDA. This inconsistency may be due to the loss of enzyme activity caused by GDA cross-linked to important active enzyme sites (Sojitra et al., 2017). Nano-sized particles retained $54.7 \%$ remaining activity after five cycles. Several factors were responsible for the better performance of microparticles in reusability than of the nanoparticles, but the major reason was the incomplete recycling of immobilized enzyme due to its smaller size, making it easy to stick to the coconut husk.
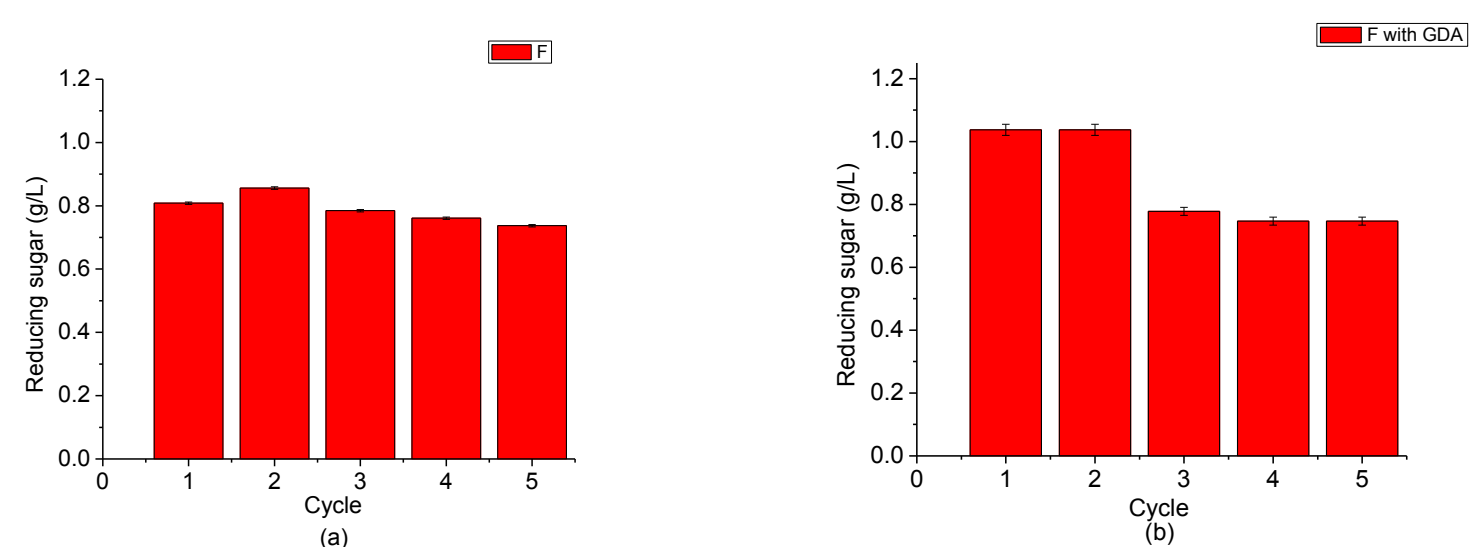

Figure 5 Reusability of: (a) chitosan magnetic microparticles; and (b) chitosan magnetic microparticles + GDA

\section{CONCLUSION}

Cellulase and xylanase were successfully immobilized covalently on chitosan magnetic particles. The FT-IR spectra convinced the covalent bond and the existence of GDA. The use of cellulase and xylanase collectively in the optimum ratio significantly enhanced the yield of 
sugar, and the immobilized cellulase and xylanase could be utilized several times without loss of activity. This simultaneous use of three enzymes immobilized on chitosan magnetic particles has economic potential for use as a biocatalyst in lignocellulose hydrolysis.

\section{ACKNOWLEDGEMENT}

The authors are grateful to the Directorate General of Resources for Science, Technology and Higher Education, Ministry of Research, Technology and Higher Education of the Republic Indonesia (128/SP2H/PTNBH/DRPM/2018) for the funding provided for this study.

\section{REFERENCES}

Ahirwar, R., Sharma, J.G., Nahar, P., Kumar, S., 2017. Immobilization Studies of Cellulase on Three Engineered Polymer Surfaces. Biocatalysis and Agricultural Biotechnology, Volume 11, pp. 248-251

Alftrén, J., Hobley, T.J., 2014. Immobilization of Cellulase Mixtures on Magnetic Particles for Hydrolysis of Lignocellulose and Ease of Recycling. Biomass and Bioenergy, Volume 65, pp. 72-78

Biró, E., Németh, A.S., Sisak, C., Feczkó, T., Gyenis, J., 2008. Preparation of Chitosan Particles Suitable for Enzyme Immobilization. Journal of Biochemical and Biophysical Methods, Volume 70(6), pp. 1240-1246

Bradford, M.M., 1976. A Rapid and Sensitive Method for the Quantitation of Microgram Quantities of Protein Utilizing the Principle of Protein-dye Binding. Analytical Biochemistry, Volume 72(1-2), pp. 248-254

Chen, S.C., Sheu, D.C., Duan, K.J., 2014. Production of Fructooligosaccharides using $\beta$ fructofuranosidase Immobilized onto Chitosan-coated Magnetic Nanoparticles. Journal of the Taiwan Institute of Chemical Engineers, Volume 45(4), pp. 1105-1110

Cheng-Kang, L., Au-Duong, A.-N., 2018. Enzyme Immobilization on Nanoparticles: Recent Application. In: Emerging Areas in Bioengineering, Chang, H.N. (ed.) Wiley-VCH Verlag GmbH \& Co. KGaA, Weinheim, Deutschland, pp. 67-80

El-Ghaffar, M.A.A., Hashem, M.S., 2010. Chitosan and Its Amino Acids Condensation Adducts as Reactive Natural Polymer Supports for Cellulase Immobilization. Carbohydrate Polymers, Volume 81(3), pp. 507-516

Farinas, C.S., Loyo, M.M., Baraldo, A., Tardioli, P.W., Neto, V.B., Couri, S., 2010. Finding Stable Cellulase and Xylanase: Evaluation of the Synergistic Effect of $\mathrm{pH}$ and Temperature. New Biotechnology, Volume 27(6), pp. 810-815

Gonçalves, G.A.L., Takasugi, Y., Jia, L., Mori, Y., Noda, S., Tanaka, T., Ichinose, H., Kamiya, N., 2015. Synergistic Effect and Application of Xylanases as Accessory Enzymes to Enhance the Hydrolysis of Pretreated Bagasse. Enzyme and Microbial Technology, Volume 72, pp. 16-24

Hamzah, A., Sitompul, L.L., Irma Nurhanifah Fenda Putri, S.S., Widjaja, A., 2018. Synergistic Effect of Two Type Cellulase Immobilized on Chitosan Microparticle as Biocatalyst for Coconut Husk Hydrolysis. Indonesian Journal of Chemistry, Volume 19(2), pp. 495-502

Han, J., Rong, J., Wang, Y., Liu, Q., Tang, X., Li, C., Ni, L. 2018. Immobilization of Cellulase on Thermo-sensitive Magnetic Microspheres: Improved Stability and Reproducibility. Bioprocess and Biosystems Engineering, Volume 41(7), pp. 1051-1060

Jampala, P., Preethi, M., Ramanujam, S., Harish, B.S., Uppuluri, K.B., Anbazhagan, V., 2017. Immobilization of Levan-xylanase Nanohybrid on an Alginate Bead Improves Xylanase Stability at Wide $\mathrm{pH}$ and Temperature. International Journal of Biological Macromolecules, Volume 95, pp. 843-849

Jia, L., Gonçalves, G.A.L., Takasugi, Y., Mori, Y., Noda, S., Tanaka, T., Ichinose, H., Kamiya, 
N., 2015. Effect of Pretreatment Methods on the Synergism of Cellulase and Xylanase during the Hydrolysis of Bagasse. Bioresource Technology, Volume 185, pp. 158-164

Mahon, E., Kelly, P.M., Hristov, D.R., Pitek, A.S., Verderio, P., Rocks, L., Dawson, K.A., Thomas, S.S., 2015. Tuning of Nanoparticle Biological Functionality through Controlled Surface Chemistry and Characterisation at the Bioconjugated Nanoparticle Surface. Scientific Reports volume 5, Article number: 17040 (2015), Volume 5(1), pp. 1-8

Manrich, A., Komesu, A., Adriano, W.S., Tardioli, P.W. Giordano, R.L.C., 2010. Immobilization and Stabilization of Xylanase by Multipoint Covalent Attachment on Agarose and on Chitosan Supports. Applied Biochemistry and Biotechnology, Volume 161(1-8), pp. 455-467

Mardawati, E., Kresnowati, M., Purwadi, R., Bindar, Y., Setiadi, T., 2018. Fungal Production of Xylanase from Oil Palm Empty Fruit Bunches via Solid State Cultivation. International Journal on Advanced Science, Engineering and Information Technology, Volume 8(6), pp. 2539-2546

Miller, G.L., 1959. Use of Dinitrosalicylic Acid Reagent for Determination of Reducing Sugar. Analytical Chemistry, Volume 31(3), pp. 426-428

Mistry, B.D., 2009. A Handbook of Spectroscopic Data: UV, IR, PMR, CNMR and Mass Spectroscopy. Oxford Book Company, Apeejay House, Kolkata, India

Osuna, Y., Gregorio-Jauregui, K.M., Gaona-Lozano, J.G., De La Garza-Rodriguez, I.M., Ilyna, A., Barriga-Castro, E.D., Saade, H., López, R.G., 2012. Chitosan-coated Magnetic Nanoparticles with Low Chitosan Content Prepared in One-step. Journal of Nanomaterials, Volume 2012, pp. 1-7

Pengilly, C., García-Aparicio, M.P., Diedericks, D., Brienzo, M., Görgens, J.F., 2015. Enzymatic Hydrolysis of Steam-pretreated Sweet Sorghum Bagasse by Combinations of Cellulase and Endo-xylanase. Fuel, Volume 154, pp. 352-360

Pospiskova, K., Safarik, I., 2013. Low-cost, Easy-to-prepare Magnetic Chitosan Microparticles for Enzymes Immobilization. Carbohydrate Polymers, Volume 96(2), pp. 545-548

Safarik, I., Horska, K., Pospiskova, K., Safarikova, M., 2012. One-step Preparation of Magnetically Responsive Materials from Non-magnetic Powders. Powder Technology, Volume 229, pp. 285-289

Sánchez-Ramírez, J., Martínez-Hernández, J.L., Segura-Ceniceros, P., López, G., Saade, H., Medina-Morales, M.A., Ramos-González, R., Aguilar, C.N., Ilyina, A., 2017. Cellulases Immobilization on Chitosan-coated Magnetic Nanoparticles: Application for Agave Atrovirens Lignocellulosic Biomass Hydrolysis. Bioprocess and Biosystems Engineering, Volume 40(1), pp. 9-22

Sangian, H.F., Ranggina, D., Ginting, G.M., Purba, A.A., Gunawan, S., Widjaja, A., 2015. Study of the Preparation of Sugar from High-lignin Lignocellulose Applying Subcritical Water and Enzymatic Hydrolysis: Synthesis and Consumable Cost Evaluation. Scientific Study and Research: Chemistry and Chemical Engineering, Biotechnology, Volume 16(1), pp. 13-27

Shahrestani, H., Taheri-Kafrani, A., Soozanipour, A., Tavakoli, O., 2016. Enzymatic Clarification of Fruit Juices using Xylanase Immobilized on 1,3,5-triazine-functionalized Silica-encapsulated Magnetic Nanoparticles. Biochemical Engineering Journal, Volume 109, pp. 51-58

Sojitra, U.V., Nadar, S.S., Rathod, V.K., 2017. Immobilization of Pectinase onto Chitosan Magnetic Nanoparticles by Macromolecular Cross-linker. Carbohydrate Polymers, Volume 157, pp. 677-685

Song, H.T., Gao, Y., Yang, Y.-M., Xiao, W.-J., Liu, S.-H., Xia, W.-C., Liu, Z.-L., Yi, L., Jiang, Z.-B., 2016. Synergistic Effect of Cellulase and Xylanase during Hydrolysis of Natural Lignocellulosic Substrates, Bioresource Technology, Volume 219, pp. 710-715 
Soozanipour, A., Taheri-Kafrani, A., Landarani Isfahani, A., 2015. Covalent Attachment of Xylanase on Functionalized Magnetic Nanoparticles and Determination of Its Activity and Stability. Chemical Engineering Journal, Volume 270, pp. 235-243

Stockton, B.C., Mitchell, D.J., Grohmann, K., Himmel, M.E., 1991. Optimum Beta-Dglucosidase Supplementation of Cellulase for Efficient Conversion of Cellulose to Glucose. Biotechnology Letters, Volume 13(1), pp. 57-62

Xu, J., Huo, S., Yuan, Z., Zhang, Y., Xu, H., Guo, Y., Liang, C., Zhuang, X., 2011. Characterization of Direct Cellulase Immobilization with Superparamagnetic Nanoparticles. Biocatalysis and Biotransformation, Volume 29(2-3), pp. 71-76

Yuan, Y., Luan, X., Rana, X.K., Hassan, M.E., Dou, D., 2016. Covalent Immobilization of Cellulase in Application of Biotransformation of Ginsenoside Rb1. Journal of Molecular Catalysis B: Enzymatic, Volume 133(1), pp. 1-8

Zang, L., Qiu, J., Wu, X., Zhang, W., Sakai, E., Wei, Y., 2014. Preparation of Magnetic Chitosan Nanoparticles as Support for Cellulase Immobilization. Industrial and Engineering Chemistry Research, Volume 53(9), pp. 3448-3454 